\title{
SIKAP KELUARGA DALAM PEMANFAATAN POSYANDU LANSIA DI PUSKESMAS KOTA BANDAR LAMPUNG
}

\author{
Sary Febriaty ${ }^{1^{*}}$, Efa Trisna ${ }^{2}$, Gustop Amatiria ${ }^{3}$ \\ 1,2,3 Jurusan Keperawatan Tanjungkarang Poltekkes Tanjungkarang \\ *Email Korespondensi : febriatysary@gmail.com
}

\section{ABSTRACT: FAMILY ATTITUDES IN UTILIZING POSYANDU LANSIA IN PUSKESMAS KOTA BANDAR LAMPUNG}

Introduction: In 2020 it is estimated that the number of elderly people will increase by $11.09 \%(29,120,000$ more $)$ with a life expectancy of $70-75$ years. Data from the Lampung Provincial Health Office, the number of elderly people 89,1061 people, while data from the city of Bandar Lampung the number of elderly people in 2016 was 3,893 people. The number of elderly people in the working area of the Rajabasa Health Center is 3,893 people. The number of elderly visits to the Elderly Posyandu was 1,854 people. A survey conducted on 10 - 14 April 2018 of 15 elderly who did not visit the posyandu stated that they had difficulty going to the posyandu because no one was there to assist them.

Purpose: This study aims to determine the attitude of the family towards the use of Posyandu for the elderly in the working area of the Rajabasa Public Health Center, Bandar Lampung City.

Methods: The research design used in this study is qualitative research, namely research that produces descriptive data in the form of written or spoken words from the community and observable behavior in the form of family attitudes towards the use of posyandu for the elderly in the work area. Rajabasa Health Center, Bandar Lampung City. .

Results: The results showed that the low level of family involvement in the use of posyandu for the elderly.

Conclusion: For health workers and other community leaders to motivate families to be involved in the Elderly Posyandu.

Keywords: Family, Elderly, Posyandu

\section{INTISARI: SIKAP KELUARGA DALAM PEMANFAATAN POSYANDU LANSIA DI PUSKESMAS KOTA BANDAR LAMPUNG}

Pendahuluan: Tahun 2020 diperkirakan jumlah lanjut usia akan meningkat 11.09\% (29.120.000 lebih) dengan umur harapan hidup 70 - 75 tahun. Data dari Dinas Kesehatan Provinsi Lampung jumlah lansia 89.1061 orang sedangkan data kota Bandar Lampung jumlah lansia pada tahun 2016 sebanyak 3.893. Jumlah lansia diwilayah kerja Puskesmas Rajabasa sebanyak 3.893 orang. Jumlah kunjungan usia lanjut ke Posyandu Lansia sebanyak 1.854 orang. Survey yang dilakukan pada tanggal 10 - 14 April 2018 terhadap 15 lansia yang tidak melakukan kunjungan ke Posyandu mengatakan bahwa mereka kesulitan untuk berangkat ke Posyandu karena tidak ada yang menemani.

Tujuan: Penelitian ini bertujuan mengetahui Sikap Keluarga Terhadap Pemanfaatan Posyandu Lansia di Wilayah kerja Puskesmas Rajabasa Kota Bandar Lampung. 
Metode: Desain penelitian yang digunakan pada penelitian ini merupakan penelitian kualitatif, yaitu penelitian yang menghasilkan data deskriptif berupa kata-kata tertulis atau lisan dari orang-orang dan perilaku yang dapat diamati berupa sikap keluarga terhadap pemanfaatan Posyandu lansia di wilayah kerja Puskesmas Rajabasa Kota Bandar Lampung.

Hasil: Hasil dari penelitian ini, yaitu didapatkan rendahnya keterlibatan keluarga dalam pemanfaatan Posyandu lansia.

Kesimpulan: Agar petugas kesehatan dan tokoh masyarakat lainnya memotivasi keluarga untuk keterlibatannya dalam Posyandu Lansia.

Kata kunci: Keluarga, Lansia, Posyandu

\section{PENDAHULUAN}

Keberhasilan pembangunan
nasional memberi dampak meningkatnya umur harapan hidup waktu lahir (UHH). Undang-undang kesehatan nomor 36 tahun 2009 menyebutkan bahwa upaya untuk meningkatkan dan memelihara kesehatan masayarakat termasuk lanjut usia dilaksanakan berdasarkan prinsip non diskrinatif, partisipatif dan berkelanjutan.

Tahun 2020 diperkirakan jumlah lanjut usia meningkat $11.09 \%$ (29.120.000 lebih) dengan umur harapan hidup 70 - 75 tahun. Data dari Dinas Kesehatan Provinsi Lampung jumlah lansia 89.1061 orang sedangkan data kota Bandar lampung, jumlah lansia di wilayah kerja rajabasa sebanyak 3.893 orang. Jumlah kunjungan usila ke Posyandu lansia sebanyak 1.854 .

Jika dilihat dari angka kunjungan lansia ke posyandu hampir separuh dari lansia tidak berkunjung ke posyandu, padahal posyandu lansia merupakan wadah untuk pelayanan kesehatan bagi lansia. Kegiatan-kegiatan yang dilaksanakan di posyandu lansia berupa pengobatan, senam, penyuluhan kesehatan yang merupakan pelayanan unytuk mencegah penyakit dan meningkatkan kesehatan lansia. Survey yang dilakukan pada tanggal 10 - 14 april 2018 terhadap 15 lansia yang tidak melakukan kunjungan ke posyandu mengatakan mereka kesulitan untuk berangkat ke posyandu karena tidak ada yang menemani.

Ketidaktahuan masyarakat, baik keluarga maupun usia lanjut itu sendiri serta para pembuat keputusan dan pemberi pelayanan terhadap permasalahan kelanjut usiaan, akan menghambat pencapaian lanjut usia sehat sejahtera dan produktif. Akibat lain dari stigma masyarakat terhadap lanjut usia ini adalah terhambatnya pemenuhan kebutuhan dir mereka untuk berkembang serta berpartisipasi didalam pembangunan (Zainaro, 2021).

Berdasarkan uraian tersebut, maka peneliti tertarik untuk melakukan penelitian tentang hubungan,persepsi dan sikap keluarga dengan pemafaatan Posyandu Lansia Bandar Lampung.

\section{METODE}

Penelitian ini merupakan penelitian kualitatif, yaitu penelitian yang menghasilkan data deskriptif berupa kata-kata tertulis atau lisan dari orang-orang dan perilaku yang dapat diamati (Bogdan Taylor,1975 dikutip dalam Moleong, 2000). Penelitian ini dilakukan pada bulan juli - september tahun 2018, dengan lokasi penelitian adalah di seluruh posyandu di wilayah kerja Puskesmas Rajabasa kota Bandar Lampung. Dengan jumlah informan 
sebanyak 14 orang yang terdiri dari Kepala Puskesmas ( 1 Orang ), Petugas Puskesmas (2 Orang), Kader ( 1 orang), Keluarga Lansia (10 orang). Teknik pengumpulan data menggunakan pedoman wawancara (wawancara mendalam). pedoman FGD dan lembar observasi. Analisis data dalam penelitian ini menggunakan analisis data model interaktif dari Miles dan Huberman (1992) yang terdiri dari 3 komponen analisis yaitu data reduction (reduksi data), data display (penyajian data) dan conclusion drawing/verification (penarikan kesimpulan).

\section{HASIL}

Pengumpulan data menggunakan pedoman wawancara, pedoman FGD dan lembar observasi.

Pernyataan informan tersebut akan diberi sandi - sandi sebagai berikut:

(K) : Pernyataan dari informan keluarga lansia yang memanfaatkan posyandu lansia.

(P) : Pernyataan dari petugas kesehatan dan kepala puskesmas.

(D) : Pernyataan dari dokter, perawat dan kader posyandu.

\section{Karakteristik Informan}

Karakteristik yang dibahas dalam penelitian ini meliputi umur, pendidikan, pengetahuan, pekerjaan. Jumlah informan dalam penelitian ini adalah 10 orang yang merupakan keluarga dari lansia ,satu orang petugas puskesmas, satu orang dokter puskesmas dan satu orang dari kader puskesmas.

\section{a. Umur}

Umur informan kelurga lansia yang memanfaatkan posyandu yaitu rata-rata umur 38 tahun,.Umur informan kunci dokter puskesmas 40 tahun dan petugas kesehatan 30 tahun dan kader kesehatan 45 tahun.

b. Pendidikan

Tingkat pendidikan informan keluarga lansia yang memanfaatkan posyandu lansia rata rata tamat SMP. Sedangkan tingkat pendidikan informan kunci sarjana dan untuk kader tingkat pendidikanya SD.

\section{c. Pekerjaan}

Seluruh informan keluarga lansia yang memanfaatkan posyandu lansia adalah sebagai ibu rumah tangga yang tidak bekerja. Jenis pekerjaan kepala keluarga dari informan keluarga lansia yang memanfaatkan posyandu lansia ditemukan hanya dua jenis yaitu buruh dan sopir.

\section{Pengetahuan pengertian Posyandu \\ tentang}

Untuk mengetahui pengetahuan tentang pengertian posyandu hampir semua informan bisa mengungkapkan bahwa posyandu lansia adalah posyandu yang di peruntukan untuk orang tua, seperti yang di ungkapkan berikut:

"ya posyandu yang seperti anak balita tapi yang datang nenek nenek yang sudah tua' $(K)$

'yo posyandu sing kanggo cah cilik tapi seng teko mbah-mbah wes tuek'\{K2\}

Pos pelayanan terpadu untuk orang tua dan kadang nenek juga bawa cucungnya"(K2)

Pos pelayanan terpadu guwai ulun tuhow jomow kadang nyanyik sai ngebow cucung now

Pelayanan inow gegoh posyandu sanak lunik.

\section{Dorongan Mengunjungi Posyandu \\ Untuk mengetahui dorongan} untuk mengunjungi posyandu lansia, pertanyaan meliputi dari mendapatkan informasi terhadap posyandu lansia, bagaimana sikap petugas kesehatan. Untuk informasi keluarga pada umumnya menjawab bahwa di umumkan di masjid.

Dari manakah bapak ibu mendapat informasi tentang posyandu dan bentuk penyuluhan : 
- Biasanya diumumkan di masjid dekat rumah(K1)

'biasane diumumke lewat masjid' $\{K 2\}$

'biasonow di umumken dimesjet paghok now ikam' $\{K 3\}$

Bagaimanakah petugas kesehatan dalam memberikan penyuluhan :

'biasane pelayanan kesehatan ngekei pelayanan sengapik'\{K2\}

'petugas now sangat wawai ,ramah tamah " $\{K 3\}$

\section{Pemanfaatan Posyandu}

Untuk mengetahui tentang pemanfaatan posyandu lansia. Pada umumnya informan tidak memahami tentang posyandu lansia dan dukungan dari keluarga sangat kecil ketika kegiatan pos yandu lansia, Hampir semua mengungkapkan pendapatnya bahwa untuk kegiatan posyandu lansia tidak perlu ada dukungan dari keluarga, beberapa informan mengatakan malah tidak mengetahui kapan jadwal posyandu, dan bahkan ada informan mengatakan tidak peduli dari kegiatan posyandu lansia sepeti yang di ungkapkan oleh informan berikut ini :

1. Keluarga

Kami kurang setuju ada posyandlansia, karena merepotkan keluarga untuk mengantar, kecuali kalo anak kecil ia perlu di antar untuk penyuluhan

" kami ora setuju karo enek nepenyuluhan posyandu wong tuo' $\{K 2\}$

" ikam mak setujeu dengan wat now penyuluhan posyandu lansia' $\{K 3\}$

“ jarang' \{K2\}

“ jaghang sekalei, kaca hikam mak setujeu lamun keluargo ikam adok pok posyandu $\{K 3\}$

Sedangkan untuk pertanyaan mengenai Jika lansia tidak mampu mengikuti posyandu lansia apakah tindakan yang dilakukan 'ora bakal ngelakoni opo-opo' \{K2\} 'pihak keluargho mak ngelakukennyow-nyow kacah pihak keluargho mak setujeu'\{K3\}

Bagaimakah tanggapan bapak atau ibu jika ada tetangga yang tidak tahu tentang posyandu lansia padahal ada lansia di keluarga tersebut

'jarkowae' \{K2\}

'ikam kenaiken gawoh, tetapi apabila wat keluargho lansia sai membutuhken penyuluhan inow maka ikam jelasken semampu ikam' $\{K 3\}$

Jika ada lansia yang tidak mau mengikuti paosyandu apa yang ibu bapak lakukan

'jarkowae' \{K2\}

'ikam akan ngejuk informasi tentang penyuluhan posyandu inow, amen iyow mak buguh maka ikam kejahken gawoh'\{K3\}

Bagaimanakah tanggapan bapak ibu jika ada penyuluhan di posyandu lansia?

“ kami ora peduli' $\{K 2\}$

"mungkin amen di desa ikam setujeu gawoh, tetapi menurut ikam pribadi mak akan nutuk penyuluhan inow' $\{K 3\}$

"ikam kurang pandai tapi mungkin wat separeu sai nutuk' $\{K 3\}$

Menurut ibu/bapak sudah menarik kah kegiatan yang ada di posyandu lansia, jelaskan alasannya?

'cirung, kereno kegiatan iku juga iso gawe wong tuo jenuh' $\{K 2\}$

'menurut masyarakat sai baghih mungkin menarik, tetapi menurut ikam kurang cutik menarik' \{K3\}

\section{Petugas}

Untuk mengetahui sikap keluarga dalam pemanfaatan Posyandu Lansia di Wilayah Kerja Puskesmas Raja Basa Kota Bandar Lampung, maka hal-hal yang akan ditanyakan pada petugas kesehatan yaitu kepada Dokter dan Perawat yang bertugas di Posyandu adalah mengenai sikap keluarga mengenai program pengobatan, program penyuluhan 
dan program pelayanan di posyandu lansia.

Dan dari hasil wawancara yang telah dilaksanakan baik dari Dokter maupun Perawat yang bertugas di Posyandu Lansia, kami medapatkan hasil bahwa Para Keluarga kurang mendukung adanya kegiatan Posyandu Lansia, hal ini dapat dilihat dari hasil wawancara dengan petugas kesehatan bahwa mereka memberikan penjelasan banyaknya keluarga yang belum memahami manfaat dari posyandu lansia, belum paham tentang program apa saja yang ada di Posyandu Lansia, kemudian masih kurangnya kesadaran keluarga untuk mendukung atau mengantar para lansia datang ke posyandu lansia, dan keluarga juga tidak mau mendukung kegiatan-kegiatan yang dilaksanakan oleh posyandu lansia yang ada di wilayah kerja Puskesmas Rajabasa Kota Bandar Lampung. Seperti yang diutarakan sebagai berikut :"selama ini sih kami agak susah mengumpulkan para lansianya, walaupun sudah diumumin sehari sebelumnya, karena lansia-lansia didaerah sini kebanyakan kurang diperhatiin sama keluargnya, jadi kalo lansia yang keperluan sehariharinya sudah banyak bergantung dengan orang lain/keluarga, jarang dating karna gak ada yang anter, tapi kalo yang masih kuat, yang masih bias pegi-pegi sendiri kadang mereka dating sih." $(P)$

"klo di posyandu ini sama aja sih mba, gak terlalu rame, karna keluarga kayanya kurang mendukung kalo para lansia ikut posyandu lansia, mungkin karna , mungkin juga keluarga kurang paham kalo posyandu lansia itu penting bagi lansia." $(P)$

Salah seorang petugas kesehatan juga ada yang memberikan pernyataan sebagai berikut :

"kalo kami sih tetep terus mengingatkan para keluarganya, supaya mau mendukung kegiatan posyandu lansia ini, karenakan posyandu lansia ini sebenarnya sangat bermanfaat sekali bagi lansia, kadang kami mendatangi rumah keluarga lansia loh, untuk kasih penjelasan tentang apa itu posyandu lansia, apa aja programnya, tapi ya masih tetep aja, kurang dapet dukungan..." (D) Sedangkan menurut petugas kesehatan, jika ada kegiatan di posyandu lansia sangat sedikit sekali yang ikut berpartsipasi, seperti pernyataan berikut :

"sepi mba,, jarang banget yang mau ikut kegiatan-kegiatan kita, karna keluarganya juga gak perhatian dan gak mau ngingetin silansianya buat ikutan" (P1)

Kadang ada bulan ini datang bulan besok ga datang, malah ada yang yang berbulan-bulan ga datang “ "jarang sih keluarga yang nemenin dan ikut kegiatan sampe selesai, alesannya buru-buru ada kerjaan" (D)

\section{PEMBAHASAN}

Pengumpulan informasi
menggunakan metode WM (wawancara mendalam), hal ini disebabkan karena informan untuk pengumpulan data khususnya keluarga tidak banyak ditemukan, karena kurangnya keluarga lansia yang datang mengantar lansia untuk berkunjung ke posyandu lansia.

Dari Gambaran karakteristik menunjukkan bahwa ada kecenderungan hubungan antara karakteristik umur, tingkat pendidikan dan pekerjaan terhadap sikap keluarga dalam pemanfaatan posyandu lansia.

Para informan mendefinisikan bahwa posyandu lansia merupakan posyandu seperti Posyandu balita tapi yang datang nenek nenek yang sudah tua atau para orang tua.

Sedangkan menurut Notoatmodjo, 2007 , Posyandu 
Lansia atau Kelompok Usia Lanjut adalah suatu wadah pelayanan bagi usian lanjut di masyarakat, dimana proses pembentukan dan pelaksanaannya dilakukan oleh masyarakat bersama lembaga swadaya masyarakat (LSM), lintas sector pemerintah dan non pemerintah, swasta, organisasi social dan lain-lain, dengan menitik beratkan pelayanan pada upaya promotif dan preventif.

Menurut petugas kesehatan di Posyandu bahwa kegiatan pelaksanaan posyandu lansia biasanya sudah dijadwalkan, dan petugas puskesmas akan menyampaikan kepada kader untuk dapat diumumkan di wilayah posyandunya masing-masing. Kadang pula petugas di puskesmas rajabasa langsung memberitahu kepada lansia atau keluarga yang memiliki lansia jika akan dilaksanakan kegiatan posyandu lansia. Akan tetapi walaupun sudah diberitahu sebelumnya masih banyak keluarga yang memiliki lansia tidak dapat hadir pada saat kegiatan posyandu berjalan.

Secara umum pengetahuan informan khususnya keluarga lansia tentang manfaat posyandu masih sangat kurang, hal ini disebabkan karena mereka tidak ingin dan tidak mau tahu tentang apa itu posyandu, walaupun petugas kesehatan sudah sangat sering memberikan penjelasan tentang manfaat posyandu lansia secara rutin baik di Puskesmas maupun saat Posyandu lansia berlangsung. Dengan demikian ada kecenderungan hubungan antara sikap dengan pengetahuan keluarga lansia tentang manfaat posyandu lansia. Penyuluhan, pemberitahuan yang sangat sering diharapkan dapat meningkatkan pengetahuan dan kesadaran keluarga lansia untuk dapat berperan dalam meningkatkan pelaksanaan kegiatan posyandu lansia.

\section{KESIMPULAN}

Karakteristik demografi informan bervariasi dalam hal umur dan tingkat pendidikan. Keluarga lansia yang memanfaatkan posyandu lansia rata-rata adalah tamatan SMP. Sedangkan tingkat pendidikan dari informan kunci sarjana, dan untuk kader tingkat pendidikannya SD. Untuk pekerjaan seluruh informan keluarga lansia yang memanfaatkan posyandu lansia adalah sebagai ibu rumah tangga yang tidak bekerja.

Pada tingkat pengetahuan, kelompok informan keluarga lansia yang memanfaatkan posyandu lansia pada umumnya memberikan pendapat tahu tentang posyandu lansia, tetapi pada pertanyaan tentang program apa saja yang ada pada posyandu lansia, pad aumumnya menjawab tidak mengerti.

Dorongan keluarga untuk memanfaatkan posyandu lansia masih sangat kurang sehingga pemanfaatan posyandu lansia juga kan berkurang

Kurangnya

pemahaman keluarga tentang manfaat posyandu lansia dan dukungan yang diberikan keluarga kepada lansia yang masih sangat kecil ketika ada kegiatan posyandu lansia, meyebabkan hampir semua keluarga lansia mengungkapkan pendapatnya bahwa untk kegiatan posyandu lansia, lansia kurang mendapat dukungan dari keluarga, bahkan ada beberapa informan yang mengatakan malah tidak mengetahui kapan jadwal posyandu lansia dilaksanakan, dan ada juga informan yang mengatakan tidak peduli terhadap pelaksanaan kegiatan posyandu lansia.

Yang harus dilakukan oleh petugas Puskesmas adalah berkoordinasi dengan aparat desa dalam mengaktifkan peran keluarga untuk selalu memotivasi para lansianya. 
Dalam penelitian ini perlu dilakukan studi kuantitatif untuk melihat kemungkinan adanya hubungan antara tingkat pendidikan

\section{DAFTAR PUSTAKA}

Alimuzul, Aziz. (2008). Riset Keperawatan dan Teknik Penulisan Ilmiah, Jakarta: Salemba Medika.

Arikunto, Suharsini. (2010). Prosedur Penelitian Suatu Pendekatan Praktek, Jakarta: Rineka Cipta Departemen Sosial RI. (2004). Undang-undang Republik Indonesia No.13, tahun 1998, tentang Kesejahteraan Lanjut Usia.

Devi. (2011) Hubungan Persepsi dan Sikap Kepala Keluarga Terhadap Pemanfaatan Kelurahan Tuah Karya Siaga Kecamatan Tampan kota Pekan Baru tahun 2011

Direktorat Bina Pelayanan Sosial Lanjut Usia, Depsos RI. (2012) Lanjut Usia dalam Data \& Informasi.

Hastono, Sutanto Priyono. (2016). ANalisa Data, FKM-UI.

Hastono, Sutanto Priyono. (2016). Analisis Pelaksanaan Posyandu Lansia di Wilayah Kerja dengan pemanfaatan posyandu lansia.
Puskesmas Ambacang Kota Padang Tahun 2016

Komisi Nasional Lanjut Usia. (2007). Menua Secara Aktif, Kerangka Kebijakan, Jakarta 2007

Komisi Nasional Lanjut Usia. (2010) Pedoman Pelaksanaan Posyandu Lansia.

Moleong, L. J. (2000). Metode Penelitian Kualitatif. Bandung: PT Remaja Rosdakarya

Notoatmodjo, Soekidjo. (2010). Metodologi Peneliian Kesehatan, Jakarta: Rineka Cipta.

Wawan dan Dewi. (2010). Teori dan Pengukuran, pengetahuan, sikapdan Perilaku Manusia, Yogyakarta, Nuha Medika, 2010.

Zainaro, M. A. (2021). The Leadership and Motivation on Inpatient Compliance in Preventing the Risk of Patients Falling. Psychology and Education Journal, 58(2), 241253. 